\title{
TOMMASO ALPINA:
}

\section{Subject, Definition, Activity. Framing Avicenna's Science of the Soul (Volume 28 in the series Scientia Graeco-Arabica)}

\author{
Berlin: De Gruyter 2021, 266 s.
}

Does the science of the soul belong to Physics or Metaphysics? This problem has distressed the whole history of Aristotelianism (and any philosophical system depending thereon) usually in connection with particular issues, for example, whether the soul is immortal or in what sense the intellect is immaterial. It is praiseworthy that Alpina discusses in his book the underlying epistemological framework for the science of the soul, which should help answer problems otherwise piecemeal approached. He methodologically arranges his monograph according to the title's three concepts: What is the subject matter of the science of the soul? How should we define the soul? What is its proper activity? These questions are valid for any author inspired in De Anima. Alpina here reconstructs Avicenna's elaborate answer focusing on the Kitāb al-Nafs (Book of the Soul, henceforth Nafs), the sixth section

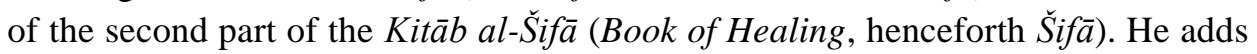
as an appendix a translation of the relevant passages of the Nafs.

Alpina's study is divided in six chapters. Chapters 1 and 2 contextualize his research. In the first one, the Nafs is described in the context of the Šif $\bar{a}$ and in relation to the De Anima. In chapter 2, Alpina summarizes the status quaestionis of the epistemology of the soul as Avicenna received it from the Aristotelian tradition (that is to say, from Neoplatonic and Arabic interpretations). Aristotle himself wavers on the issue, for he, on the one hand, advocates for the study of the soul as a part of natural philosophy but, on the other hand, seems uneasy whether physics can really study all souls, because the intellect seems separate. The Aristotelianism previous to Avicenna advanced three sorts of solution, according to Alpina: $\langle\mathrm{a}\rangle$ a naturalistic approach, such as Alexander of Aphrodisias', according to which the study of the soul is a general introduction to biology; $\langle\mathrm{b}\rangle$ the soul is the culmination of physics and an anticipation of metaphysics, advanced by the Alexandrian commentators and Al-Farabi, in whose view the science of the soul lifts up to the transcendent causes coincident with ethics and metaphysics; <c> middle ontology of the soul, championed by Al-Kindi, who holds the soul belongs to both sciences. 
Chapters 3 to 5 expound Alpina's interpretation of the Nafs. Chapter 3 advances epistemological criteria for categorizing the soul. Following the Aristotelian ideal of science, Avicenna sets Metaphysics at the top, which is characterized as the only science which demonstrates the existence and quiddity of its subject matter. Now, the science of the soul does demonstrate its existence and quiddity, for Avicenna holds that the soul is self-existent as demonstrated from the "flying man argument", which Alpina reads as an argument for the independent existence of the soul. Moreover, Avicenna holds that the soul is a substance, because it is not "in-asubject" (i.e. it is not an accident). Furthermore, the soul is immaterial, given the universal objects of its faculties and its infinite power in reason and will. All of this points to metaphysics as the proper science of the soul, yet Avicenna wishes to maintain the unity of the study of the soul, which also includes the lower souls with lesser faculties. That is why, in Alpina's reading, Avicenna is content with the description of soul as a "living principle", which may or may not mean the form of a body.

Chapter 4 provides the following step for a unitary definition of the soul under the category of "perfection", which applies to both form and substance. The notion of perfection, which derives from the Greek commentators of Aristotle, is understood to encompass separable or inseparable actualities, actualities in themselves or the causes of such. Avicenna accordingly defines the soul as a perfection, here in the sense of a separate substance which is also the principle of capacities of a living being. Hence, it is a living principle connected to a body, but it is not a form of a corporeal being. The body is understood as an instrument and a principle of individuation, which is related to the soul but not informed by it. The relation endures after death, in order to secure its individuality related to the personal history.

Chapter 5 discusses intellection, which at best displays the physical/metaphysical duality of the soul. The soul goes "downward" to retrieve the particular forms and "upwards" to receive illumination from the active intellect. Alpina reviews here the controversy on how to understand the relation between the activity of the soul and the emanation coming from the higher intellectual sphere. Alpina is inclined to highlight the role of the lower faculties, which progressively abstract the forms received through the senses. The active intellect then shines over the abstracted form stored in the imagination and is actively inspected by the human intellect. Thus, the soul - even if substantial and not properly the form of the body - acts in strict unity with the body.

In the last chapter, Alpina reviews Avicenna's other summae, but only insofar as they provide a genetic context of the doctrines enounced in the Nafs. The summae 
tend to discuss the human soul only at the end of natural philosophy, thus, the soul seems to really belong to metaphysics.

The monograph is a revised version of the author's PhD dissertation submitted in 2016. Indeed, the book's presentation, as found in the introduction and conclusion, retains some typical elements of a thesis: a clearly delimited problem is tackled, and the originality of the research is repeatedly asserted. That being said, the text flows naturally and the structure and aims are clearly spelled out without obtrusive repetitions.

This reviewer praises Alpina's monograph, which is both an introduction to the epistemology of the soul in Avicenna (and in Aristotelianism in general) as well as a well-argued interpretation. The book follows a correct methodology, insofar as it poses three clear questions to test the ontology of the soul, i.e., Is the soul an object by itself or is it primarily a principle of a corporeal living being? Is there some unifying notion which may explain its independence and relation to the living being? Does it display some activity which connects its substantial and relational being? These three questions are answered in the three central chapters, which correspondingly assert the soul to be primarily substantial, a perfection and intellective of the enmattered forms. Along the same lines, this reviewer commends Alpina's balanced and circumscribed presentation of modern interpretations on illumination and abstraction in Avicenna. Moreover, Alpina insightfully traces the concept of perfection back to Alexander and Philoponus, thus showing how Avicenna creatively put said metaphysical concept to new use.

This reviewer, however, is puzzled on the order of the chapters: each of them reads as an independent research (indeed, Alpina remarks that some chapters or sections were previously published as articles). Chapter 4 should perhaps come before chapter 3, where the general notions for explaining the soul are given. Moreover, the review of the summae in chapter 6 studies mainly their table of contents, which seemed more logical and informative if placed after chapter 1, which outlines the Nafs. Furthermore, Alpina seems to forget the epistemological approaches of the Greek commentators he reports in chapter two. This reviewer did not find any useful comparison of Avicenna's solution with those views, whether to indicate that Avicenna thinks that the soul is purely metaphysical as the "culmination" group does or whether he is rather similar to the "intermediate" group. In that sense, although the book impressively explains Avicenna, it is hard to position him in the wider context of Aristotelianism, be it relating to his predecessors or those influenced by Avicenna.

For a final word, this reviewer heartily recommends Alpina's treatise for researchers of the reception of Aristotelian psychology, for Alpina presents a convincing 
account of Avicenna's complex epistemology for the soul, with plentiful tensions, as any treatment of the soul has always been.

Alfonso Herreros

\author{
Alfonso Herreros \\ Pontificia Università della Santa Croce \\ Facoltà di Teologia \\ Piazza di Sant'Apollinare 49 \\ 00186 Roma \\ Italy \\ e-mail: alfonso.herreros@gmail.com \\ ORCID ID: https://orcid.org/0000-0002-1986-9385
}

